\title{
ESTIMASI BEBAN LIMBAH ORGANIK DARI TAMBAK UDANG SUPERINTENSIF YANG TERBUANG DI PERAIRAN TELUK LABUANGE
}

\section{ESTIMATION OF ORGANIC WASTE LOADS FROM SHRIMP POND SUPERINTENSIVE THAT WAS DISPOSED IN THE LABUANGE BAY WATERS}

\author{
Mudian Paena ${ }^{1 *}$, Rajuddin Syamsuddin ${ }^{2}$, Chair Rani' ${ }^{2}$ \& Haryati Tandipayuk ${ }^{2}$ \\ ${ }^{1}$ Balai Riset Perikanan Budidaya Air Payau dan Penyuluhan Perikanan, Maros, 90512, Indonesia \\ ${ }^{2}$ Fakultas Ilmu Kelautan dan Perikanan, Universitas Hasanuddin, Makassar, 90245, Indonesia \\ "E-mail: mudianpaena@yahoo.co.id
}

\begin{abstract}
Environmental pollution in the form of organic waste containing nitrogen $(N)$ and phosphate $(P)$ sourced from superintensive shrimp pond cultivation due to much feed use is a severe problem in the development of superintensive technology in Indonesia. This study aims (1) to estimate the amount of feed wasted into the environment during cultivation in superintensive ponds and (2) estimate the amount of $N$ and $P$ waste that is wasted into the environment from superintensive cultivation. The research method is carried out in 3 stages; the first stage was carried out on a superintensive pond for 76 days by carrying out superintensive shrimp farming with a density of 600 tails / $\mathrm{m} 2$ then carried out observations of wasted feed. The second stage is to conduct laboratory-scale shrimp digestibility tests, and the third stage is laboratory-scale shrimp excretion research. The results showed that (1) the amount of feed wasted into the environment (un-eaten) amounted to $24.32 \%$ of the total feed provided. The burden of organic waste from superintensive ponds shrimp discharged into the waters of Labuange Bay is 3.89 tons/year consisting of organic waste containing $N$ amounting to 3.61 tons/year with a mean of discharging to waters of $10.31 \mathrm{~kg} /$ day, and organic waste containing $P$ of 0.28 tons/year with a mean discharge to the waters of $0.81 \mathrm{~kg} /$ day. These results indicate that the waters of Labuange Bay have experienced the pressure of organic waste originating from superintensive shrimp pond activities.
\end{abstract}

Keywords: estimation of organic waste, shrimp farming, super-intensive technology

\begin{abstract}
ABSTRAK
Pencemaran lingkungan oleh limbah organik mengandung nitrogen $(\mathrm{N})$ dan fosfat $(\mathrm{P})$ yang bersumber dari tambak udang superintensif karena penggunaan pakan yang banyak merupakan masalah serius dalam pengembangan teknologi superintensif di Indonesia. Penelitian ini bertujuan untuk mengestimasi jumlah pakan yang terbuang ke lingkungan selama budi daya di tambak superintensif dan untuk mengestimasi jumlah limbah $\mathrm{N}$ dan $\mathrm{P}$ yang terbuang ke lingkungan dari kegiatan budi daya superintensif. Metode penelitian dilakukan sebanyak 3 tahap; tahap pertama dilakukan pada tambak superintensif selama 76 hari dengan melakukan budi daya udang superintensif dengan kepadatan 600 ekor $/ \mathrm{m}^{2}$ selanjutnya dilakukan pengamatan pakan yang terbuang. Tahap kedua adalah melakukan uji kecernaan udang skala laboratorium dan tahap ketiga adalah penelitian ekskresi udang skala laboratorium. Hasil penelitian menunjukkan bahwa jumlah pakan tidak termakan yang terbuang ke lingkungan dari tambak superintensif sebesar $24,32 \%$ dari total pakan yang digunakan. Beban limbah organik dari tambak udang superintensif yang terbuang ke perairan Teluk Labuange sebesar 3,89 ton terdiri dari limbah organik mengandung $\mathrm{N}$ sebesar 3,61 ton/tahun dengan rerata buangan ke perairan $10,31 \mathrm{~kg} / \mathrm{hari}$, dan limbah organik mengandung $\mathrm{P}$ sebesar 0,28 ton/tahun dengan rerata buangan $\mathrm{ke}$ perairan $0,81 \mathrm{~kg} /$ hari. Hasil ini menunjukkan bahwa perairan Teluk Labuange telah mengalami tekanan limbah organik yang berasal dari kegiatan tambak udang superintensif.
\end{abstract}

Kata kunci: budi daya udang, estimasi limbah organik, teknologi superintensif 


\section{PENDAHULUAN}

Penerapan teknologi budi daya superintensif saat ini telah menjadi pilihan utama dalam meningkatkan produksi udang vaname. Istilah superintensif dalam budi daya udang pertama kali diperkenalkan oleh Boyd \& Clay (2002). Teknologi superintensif menerapkan padat penebaran udang diatas 300 ekor $/ \mathrm{m}^{2}$ (Wasielesky et al., 2006), bahkan telah mencapai 1.250 ekor $/ \mathrm{m}^{2}$ (Suwoyo et al., 2015). Padat penebaran yang tinggi pada sistem budi daya superintensif memberikan konsekuensi pada beban limbah yang dapat memengaruhi kelayakan habitat udang, serta lingkungan hidup perairan di wilayah sekitar budi daya (Suwoyo et al., 2017). Teknologi budi daya seharusnya bukan hanya fokus pada peningkatan produktivitas dan kualitas produk tetapi juga harus dapat mengurangi dampak sosial dan lingkungan yang negatif (Rurangwa et al., 2016). Boyd \& Tucker (2012) mengatakan bahwa limbah organik yang merupakan beban pencemaran yang besar bagi lingkungan perairan.

Limbah organik yang berasal dari tambak superintensif terdiri atas pakan yang terbuang selama budi daya, pakan yang tidak dicerna oleh udang, yang terbuang melalui feses dan eksresi udang selama pemeliharaan. Schwitzguébel \& Wang (2007) menjelaskan bahwa usaha perikanan budi daya merupakan kontributor utama meningkatnya limbah organik dan senyawa beracun dalam bentuk amonia sebagi limbah utama nitrogen $(\mathrm{N})$. Kawasaki et al. (2016) mengemukakan bahwa 20-30 \% dari total kandungan nitrogen $(\mathrm{N})$ dan fosfat $(\mathrm{P})$ dalam pakan akan terbuang ke lingkungan perairan.

Pengkayaan nutrien dalam perairan dapat menyebabkan dampak lingkungan yang serius seperti eutrofikasi (González at al., 2008). Eutrofikasi mengancam integritas ekologi dan ekonomi perairan pesisir (Williamson et al., 2017), serta degradasi ekosistem laut (Tirkaso \& Gren, 2016). Kelebihan nutrien juga akan memicu mun- culnya ganggang yang berbahaya, $H A B s$ (Harmful Algal Blooms) (Paerl, 1997).

Berdasarkan hal tersebut maka telah dilakukan penelitian yang bertujuan (1) untuk mengestimasi jumlah pakan yang terbuang ke lingkungan selama budi daya di tambak superintensif dan (2) untuk mengestimasi jumlah limbah nitrogen $(\mathrm{N})$ dan fosfat $(\mathrm{P})$ dari kegiatan tambak superintensif yang terbuang di perairan Teluk Labuange Kabupaten Barru.

\section{METODE PENELITIAN}

\subsection{Pakan yang Terbuang Selama Budi Daya}

Penelitian dilakukan pada Instalasi Tambak Percobaan Balai Riset Perikanan Budidaya Air Payau dan Penyuluhan Perikanan (BRPBAP3) yang terletak di Kabupaten Takalar. Petak tambak superintensif yang digunakan berukuran $1.000 \mathrm{~m}^{2}$ dengan ketinggian air selama budi daya dipertahankan antara 1,7-1,8 m (Figure 1). Padat penebaran udang vaname yang dibudi dayakan sejumlah 600 ekor $/ \mathrm{m}^{2}$ (PL-10). Selanjutnya udang ditumbuhkan selama 76 hari. Pada umur 1-30 hari, udang diberi pakan sebanyak 4 kali sehari (pagi, siang, sore dan malam, dengan total pakan yang diberikan sebanyak 945,60 kg. Pada umur 31-40 hari, pemberian pakan ditingkatkan menjadi 5 kali sehari (pagi, siang, sore, malam dan tengah malam), dengan total pemberian pakan sebanyak $901,10 \mathrm{~kg}$. Pada umur 41-48 hari selain dilakukan pemberian pakan sebanyak 5 kali, pemberian pakan juga ditambahkan melalui penggunaan 1 (satu) unit automatic feeder dengan total pakan sebanyak 1.099,80 kg dan saat umur 49-76 pemberian pakan juga dilakukan sebanyak 5 kali dan menggunakan 2 (dua) unit automatic feeder, dengan total pakan yang digunakan mencapai $3.608,60 \mathrm{~kg}$.

Sebanyak 4 buah jaring anco/pemantau pakan dipasang untuk memantau respons udang terhadap pakan yang diberikan. Dua jam setelah pemberian pakan termasuk pem- 
berian pakan melalui automatic feeder, dilakukan pengamatan dan pengambilan sisa pakan pada masing-masing anco.

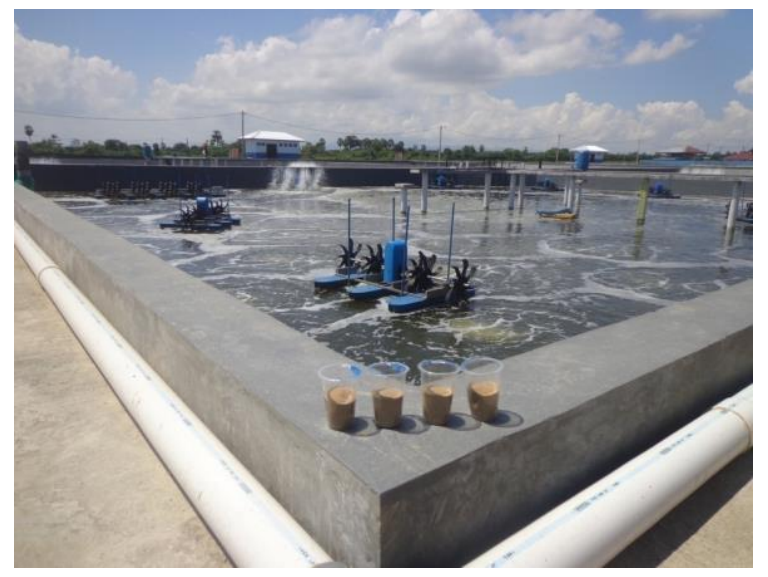

Figure 1. Superintensive pond used during the study.

Pengamatan tersebut dilakukan sebanyak 4 kali berdasarkan perubahan jenis pakan yang diberikan yaitu I pada umur udang 16 hari (kode pakan B0 dan B1), II pada umur 42 hari (kode pakan 2A), III pada umur 48 hari (kode pakan 2P) dan IV pada umur 66 hari (kode pakan 3). Sisa pakan dalam anco merupakan pakan yang terbuang. Sisa pakan tersebut selanjutnya dikeringkan dan ditimbang dalam satuan berat selanjutnya dianalisis untuk menghitung jumlah pakan yang terbuang selama kegiatan budi daya dilakukan.

\subsection{Pakan yang Tidak Dicerna oleh Udang}

Penelitian dilakukan dalam skala laboratorium. Pakan uji yang digunakan adalah pakan komersial yang memiliki kandungan protein $41,64 \%$. Jumlah pakan yang dikonsumsi udang sama dengan jumlah pakan yang diserap dan pakan yang menjadi feses. Jumlah pakan yang dimakan oleh udang dan fesesnya dapat diketahui dengan menggunakan indikator yang tidak dicerna oleh udang yaitu kromium oksida $\left(\mathrm{Cr}_{2} \mathrm{O}_{3}\right)$. Kromium oksida $\left(\mathrm{Cr}_{2} \mathrm{O}_{3}\right)$ tidak dicerna oleh udang menyebabkan konsentrasinya dalam feses akan lebih tinggi dari pada pakannya, seiring dengan nilai kecernaan pakan tersebut oleh udang. Selanjutnya dilakukan pembuatan pakan mengandung kromium oksida $\left(\mathrm{Cr}_{2} \mathrm{O}_{3}\right)$. Pakan uji ditimbang, selanjutnya dihancurkan dengan cara diblender (A) lalu ditimbang untuk menentukan jumlah kromium oksida $\left(\mathrm{Cr}_{2} \mathrm{O}_{3}\right)$ yang akan ditambahkan dalam pakan tersebut (B). Jumlah kromium oksida $\left(\mathrm{Cr}_{2} \mathrm{O}_{3}\right)$ yang ditambahkan dalam pakan sebagai indikator sebanyak 0,70\% (Furuichi, 1988) (C). Pakan dan kromium oksida $\left(\mathrm{Cr}_{2} \mathrm{O}_{3}\right)$ dicampur dengan cara dimasukkan ke dalam kantong plastik bening sehingga pakan dan kromium oksida $\left(\mathrm{Cr}_{2} \mathrm{O}_{3}\right)$ tercampur rata (D). Selanjutnya pakan dicetak ulang menjadi butiran pelet yang siap digunakan (E). Pakan yang telah dicetak selanjutnya dikeringkan dan dikemas untuk digunakan selama penelitian (F) (Figure 2).

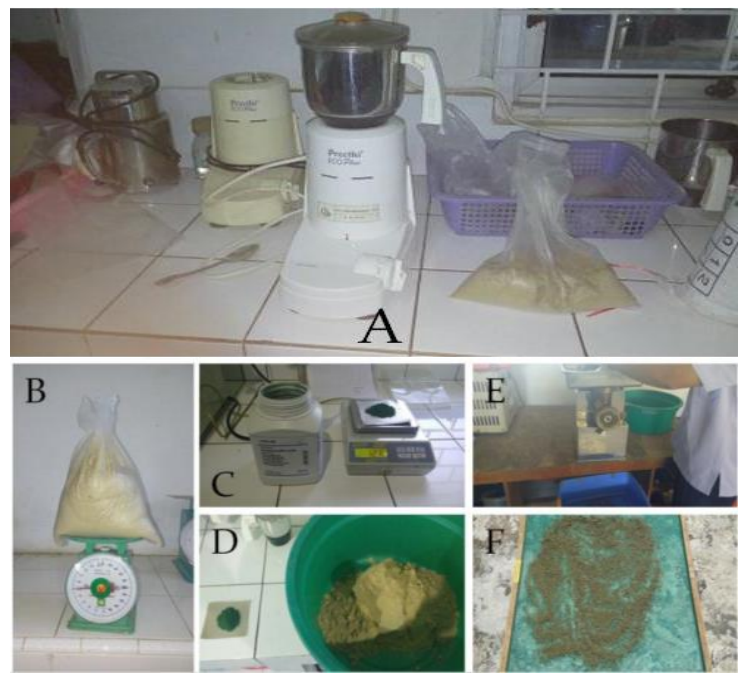

Figure 2. The process of making feed containing chromium oxide (A) feed blender, $(B)$ weigh feed that has been blended, (C) weigh chromium oxide, (D) mix feed with chromium oxide, $(E)$ feed mold, $(F)$ feed dry.

Udang yang digunakan untuk uji kecernaan terdiri atas 3 bobot yang berbeda yaitu 2-3 g, 4-5 g dan 6-7 g dengan padat penebaran 20 ekor/akuarium. Pengamatan 
dilakukan masing-masing 1 jam, 2 jam dan 3 jam setelah pemberian pakan. Ketiga bobot udang dengan 3 ulangannya dipelihara pada wadah akuarium yang berbeda dengan volume yang sama yaitu 50 L/akuarium (A). Pakan yang telah dicampur dengan kromium oksida $\left(\mathrm{Cr}_{2} \mathrm{O}_{3}\right)$ selanjutnya menjadi pakan utama diberikan pada udang selama 6 hari pemeliharaan (B). Pemberian pakan dilakukan dengan frekuensi 4 kali perhari. Jumlah pakan yang diberikan sebanyak 2,5-3\% dari biomassa udang. Pengambilan feses udang dilakukan dengan cara disedot $3 \mathrm{kali} / \mathrm{hari}$. Feses yang terkumpul disimpan dalam wadah dan segera dimasukkan ke dalam freezer untuk menghindari terjadi kehilangan nutrien (nutrient leaching) pada feses (C). Setelah cukup jumlahnya $200 \mathrm{~g}$ selanjutnya dikeringkan (E) (Figure 3).
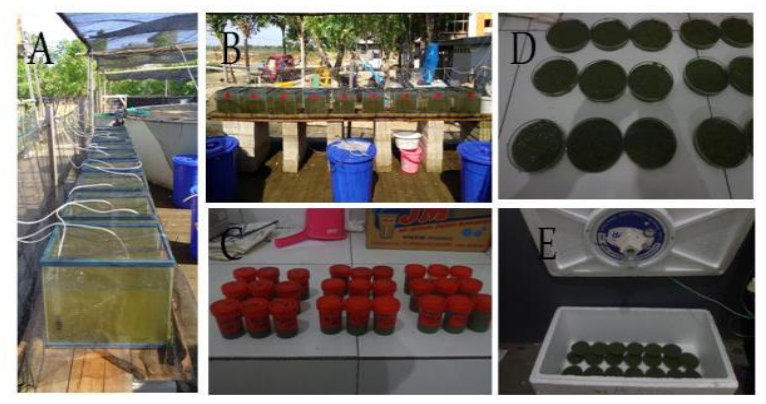

Figure 3. Process of shrimp shrimp faeces containing cromium oxide, (A) aquarium used during research, (B) chromium oxide feed given to shrimp in aquariums, (C) shrimp faecal collection, (D) faeces placed in petri dishess, $(E)$ heated faeces.

Pakan yang mengandung crom selanjutnya menjadi pakan utama diberikan pada udang selama 6 hari pemeliharaan. Pemberian pakan dilakukan sebanyak 4 kali perhari. Jumlah pakan yang diberikan sebanyak 2,5-3\% dari biomassa udang. Pengambilan feses udang mulai dilakukan pada hari 7 saat dimana telah dipastikan bahwa feses yang keluar $100 \%$ berasal dari pakan yang mengandung crom dengan cara disedot selama 3 kali setiap hari. Pemberian pakan pada pemeliharaan hari 7-12 tetap menggunakan pakan yang mengandung crom. Feses yang terkumpul disimpan dalam wadah dan segera dimasukkan ke dalam freezer untuk menghindari terjadinya leaching nutrient pada feses. Setelah cukup jumlahnya $200 \mathrm{~g}$ selanjutnya dikeringkan dalam freezydried. Kandungan nitrogen $(\mathrm{N})$ dan fosfat (P) pada feses dihitung berdasarkan metode Thakur \& Lin (2003).

\subsection{Ekskresi Udang}

Persiapan penelitian meliputi penyediaan wadah baskom warna putih berukuran 80x40x40m diisi air sebanyak 100L. Dalam wadah tersebut dimasukkan dua buah tabung kaca yang terdapat dua buah lubang, satu untuk memasukkan alat pengukur DO dan yang lainnya untuk memasukkan alat penyedot air dalam tabung. Dalam baskom tersebut dimasukkan aerasi untuk meningkatkan dan mempertahankan kadar DO dalam wadah, sedangkan dalam tabung terdapat alat yang selalu berputar yang berfungsi untuk menyeragamkan DO dalam tabung. Setelah itu dimasukkan udang di dalam tabung kaca, bersamaan dengan itu maka aerasi dalam wadah diangkat (Figure 4).

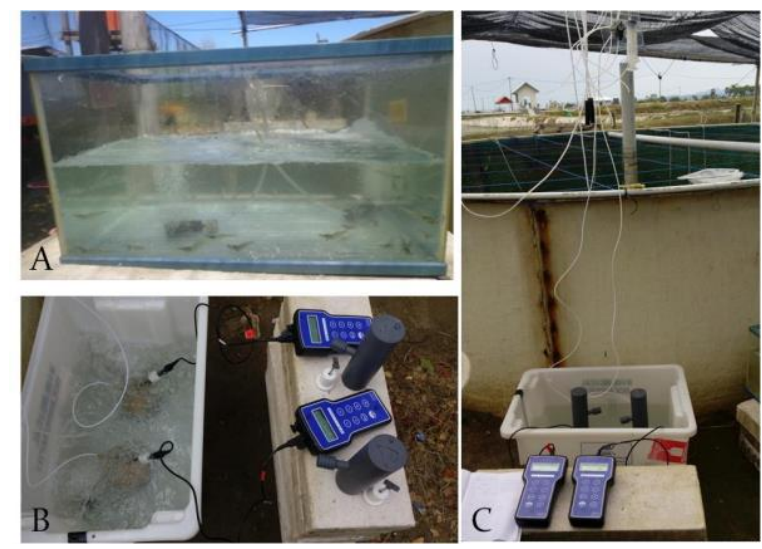

Figure 4. Process of extracting shrimp excretion data. (A) Shrimp breeding aquariums equipped with aerators, $(B)$ containers and $D O$ measuring devices, (C) water sampling using a hose connected to the spoit. 
Setelah 10 menit dilakukan pengambilan sampel air dalam tabung menggunakan spoit/ penyedot air dan dikoleksi dalam botol sampel.

Sampel air mulai diambil saat pertama udang dimasukkan wadah untuk analisis konsentrasi $\mathrm{NH}_{3}$ sebagai t0, selanjutnya sampel air diambil setelah 10 menit udang dalam wadah untuk analisis $\mathrm{NH}_{3}$ sebagai $t$. Pengambilan sampel diulang sebanyak enam kali. Sampel air selanjutnya dimasukkan ke dalam freezer. Sampling dilakukan sebanyak enam kali yaitu pada pemeliharaan 15, 21, 31, 41, 51 dan 65 hari.

\subsection{Analisis Data}

Perhitungan jumlah pakan terbuang berdasarkan formula berikut:

$P t=\sum \operatorname{SpA}$

Keterangan: Pt adalah pakan yang terbuang (g), sedangkan SpA adalah sisa pakan dalam anco $(\mathrm{g})$.

Selanjutnya persentase pakan yang terbuang dihitung dengan persamaan:

$\% P t=P t / T p x 100 \%$

Keterangan: \%Pt adalah persentase pakan yang terbuang, $P t$ adalah pakan yang terbuang (g) dan $T p$ adalah total pakan (g).

Estimasi pakan yang terbuang ke lingkungan dihitung dengan menggunakan formula sebagai berikut:

$T P t=P t(\%) x J P s b$

Keterangan: TPt adalah total pakan terbuang (ton), Pt adalah pekan terbuang (\%) dan JPsb adalah jumlah pakan selama budi daya (ton).

Pendugaan kuantifikasi limbah total nitrogen $(\mathrm{N})$ dan fosfat $(\mathrm{P})$ (TN dan $\mathrm{TP}$ ) didasarkan atas data kandungan nitrogen $(\mathrm{N})$ dan fosfat (P) dalam pakan (Barg, 1992). Pendugaan total nitrogen $(\mathrm{N})$ dan fosfat $(\mathrm{P})$ yang terbuang mengacu pada metode Thakur \& Lin (2003), dihitung dengan persamaan untuk nitrogen $(\mathrm{N})$ dan fosfat $(\mathrm{P})$ terbuang adalah total protein pakan terbuang (ton) merupakan fungsi dari pakan terbuang (ton) dikalikan dengan kandungan protein dalam pakan. Selanjutnya, total nitrogen $(\mathrm{N})$ terbuang adalah total protein pakan terbuang dibagi dengan 6,25. Total fosfat (P) merupakan pakan terbuang dikalikan dengan kandungan fosfat $(\mathrm{P})$ dalam pakan.

Koleksi feses untuk mengetahui kecernaan udang dianalisis di laboratorium untuk melihat kandungan fosfat $(\mathrm{P})$, nitrogen (N) (AOAC, 1990) dan kromium oksida $\left(\mathrm{Cr}_{2} \mathrm{O}_{3}\right)$ dengan metode ADC (Apparent Digestibility Coeficient) menggunakan formula Watanabe (1988), sebagai berikut:

$A D S=\left\{1-\left(\frac{F}{D} \times \frac{D C r}{F C r}\right)\right\} \times 100$

Keterangan: ADS adalah koefisien kecernaan merupakan fungsi dari satu dikurangi perbandingan antara \% nutrisi atau energi pakan dari feses $(F)$ dengan \% nutrisi atau energi dalam pakan $(D)$ dikalikan dengan hasil perbandingan $\%$ kromium oksida $\left(\mathrm{Cr}_{2} \mathrm{O}_{3}\right)$ dalam pakan (Dcr) dengan \% kromium oksida $\left(\mathrm{Cr}_{2} \mathrm{O}_{3}\right)$ dalam feses $(\mathrm{FCr})$.

Pengukuran TAN (Total Amonia Nitrogen) pada air dilakukan berdasarkan pada APHA (1995), sedangkan laju eksresi TAN dianalisis berdasarkan formula yang dikemukakan oleh De Carvalho et al. (2010), sebagai berikut:

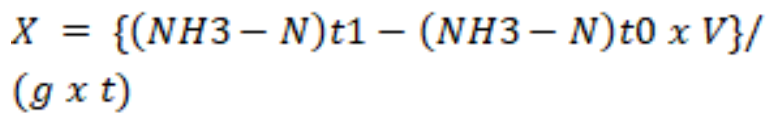

Keterangan: $\mathrm{X}$ adalah ekskresi TAN (mg/gtubuh/jam) merupakan fungsi dari pengurangan konsentrasi ammonia pada awal pengamatan (mg/L) dengan konsentrasi ammonia pada akhir pengamatan $(\mathrm{mg} / \mathrm{L})$ dikalikan dengan volume air dalam wadah, selanjutnya dibagi dengan fungsi bobot udang (g) dengan lama pengamatan.

Koefisien jumlah pakan terbuang (\%), 
kecernaan udang dan laju ekskresi udang selanjutnya digunakan untuk melakukan estimasi jumlah pakan, nitrogen $(\mathrm{N})$ dan fosfat $(\mathrm{P})$ yang terbuang di perairan Teluk Labuange. Data yang disajikan dalam Tabel selanjutnya dianalisis secara deskriptif.

\section{HASIL DAN PEMBAHASAN}

\subsection{Limbah Organik dari Pakan yang Terbuang Selama Budi Daya}

Budi daya udang vaname selama 76 hari di tambak superintensif menghabiskan pakan sebanyak 5.774,80 kg. Dari jumlah tersebut terbuang ke lingkungan sebanyak $1.404,16 \mathrm{~kg}$ (Table 1). Dengan demikian, maka jumlah pakan yang terbuang ke lingkungan sebesar 24,32\% dari total pakan yang digunakan.

Hasil estimasi pakan terbuang dari penelitian ini yang besarnya mencapai $24,32 \%$ tersebut selanjutnya digunakan untuk menghitung jumlah pakan terbuang dari kegiatan tambak superintensif yang berada di sekitar Teluk Labuange Kabupaten Barru. Hasil penelusuran data menunjukkan bahwa tambak superintensif yang berada di sekitar perairan Teluk Labuange menggunakan pakan sebanyak 150,4 ton dalam satu tahun budi daya. Dari jumlah tersebut yang terbuang ke perairan sebanyak $24,32 \%$ atau sekitar 36,58 ton pakan. Hasil analisis lanjut menunjukkan bahwa dari 36,58 ton pakan yang terbuang mengandung nitrogen $(\mathrm{N})$ yang terbuang ke perairan Teluk Labuange sebesar 2,44 ton/tahun atau $6,97 \mathrm{~kg} /$ hari dan fosfat $(\mathrm{P})$ sebesar 0,28 ton/tahun atau 0,8 $\mathrm{kg} /$ hari (Table 2).
Table 1. Test results for the percentage of feed wasted into the environment during the cultivation of vaname shrimp in a superintensive pond.

\begin{tabular}{ccc}
\hline $\begin{array}{c}\text { Sample } \\
\text { to }\end{array}$ & $\begin{array}{c}\text { Amount of } \\
\text { feeding }(\mathrm{kg})\end{array}$ & $\begin{array}{c}\text { Amount of } \\
\text { wasted feed }(\mathrm{kg})\end{array}$ \\
\hline 1 & 294.4 & 21.39 \\
2 & $1,007.40$ & 26.73 \\
3 & 705.8 & 123.4 \\
4 & $3,767.20$ & $1,232.64$ \\
\hline Total & $5,774.80$ & $1,404.16$ \\
\hline
\end{tabular}

Total produksi udang vaname di tambak superintensif di sekitar perairan Teluk Labuange sebesar 100,3 ton/tahun. Jika produksi undang tersebut dibagi dengan total $\mathrm{N}$ yang terbuang ke Teluk Labuange (2,44 ton) maka diperoleh limbah nitrogen (N) sebesar $0,023 \mathrm{~kg} / 1 \mathrm{~kg}$ udang atau 23 $\mathrm{kg} /$ ton produksi. Hasil ini lebih tinggi dari penelitian yang pernah dilakukan sebelumnya oleh Silva et al. (2013) pada teknologi semi intensif budi daya udang vaname sebesar 20 $\mathrm{kg} /$ ton produksi. Selanjutnya, produksi fosfat (P) sebesar 0,11 ton atau sekitar $2,8 \mathrm{~kg} / \mathrm{ton}$ produksi. Nilai tersebut masih dibawah nilai fosfat $(\mathrm{P})$ pada penelitian sebelumnya, yaitu 4,1 kg/ton produksi (Silva et al., 2013).

Pakan merupakan sumber utama nitrogen $(\mathrm{N})$ antara $76-92 \%$ dan fosfat $(\mathrm{P})$ antara 51-89\% (Teichert-Coddington et al., 2000). Semakin banyak pakan yang digunakan dalam sistem budi daya superintensif maka semakin besar pula potensi limbah yang terbuang ke lingkungan jika efisiensi pakan tidak tercapai.

Table 2. $N$ and $P$ contents of the feed used and feed discharged to Labuange Bay waters during vaname shrimp cultivation in superintensive ponds.

\begin{tabular}{ccccccc}
\hline Variable & $\begin{array}{c}\text { Total Feed } \\
\text { (Ton) }\end{array}$ & $\begin{array}{c}\text { Feed } \\
\text { Protein (\%) }\end{array}$ & $\begin{array}{c}\text { Feed } \\
\text { Phosphorus }(\%)\end{array}$ & $\begin{array}{c}\text { Total } \\
\text { protein in } \\
\text { feed }(\text { Ton })\end{array}$ & $\begin{array}{c}\text { Total } \\
\text { (Ton) }\end{array}$ & $\begin{array}{c}\text { Total } \\
\text { (Ton) }\end{array}$ \\
\hline $\begin{array}{c}\text { Feed during } \\
\text { cultivation }\end{array}$ & 150.45 & 41.64 & 0.77 & 62.65 & 10.02 & 1.16 \\
Wasted food & 36.58 & 41.64 & 0.77 & 15.24 & 2.44 & 0.28 \\
\hline
\end{tabular}




\subsection{Limbah Organik dari Pakan yang Tidak Dicerna oleh Udang}

Hasil analisis menunjukkan bahwa kecernaan pakan untuk ukuran udang 2-3 g sebesar 81,79\%; 4-5 g sebesar 84,38\%; dan 6-7 g sebesar $86,19 \%$ dengan rerata kecernaan sebesar $84,16 \%$. Dari hasil tersebut menunjukkan bahwa yang tidak dicerna pada berat 2-3 g sebesar 18,21\%; 4-5 g sebesar 15,62\%; dan 6-7 g sebesar $13,81 \%$ dengan rerata sebesar $15,88 \%$. Nutrien pakan yang tidak tercerna di-asumsikan terbuang ke perairan. Rerata pakan yang tidak tercerna selanjutnya digunakan untuk menentukan besarnya nitrogen $(\mathrm{N})$ dan fosfat $(\mathrm{P})$ yang terbuang di perairan Teluk Labuange yang berasal dari feses udang vaname selama kegiatan budi daya melalui pendekatan pendugaan total nitrogen $(\mathrm{N})$ dan fosfat $(\mathrm{P})$ yang terbuang mengacu pada metode Thakur \& Lin (2003). Hasil analisis memberikan informasi bahwa kandungan protein feses udang selama budi daya sebesar 4,80 ton. Dari total tersebut mengandung nitrogen $(\mathrm{N})$ sebesar 1,16 ton dan fosfat $(\mathrm{P})$ sebesar 0,0026 ton yang terbuang di perairan Teluk Labuange.

\subsection{Limbah Organik dari Ekskresi Udang}

Hasil analisis menunjukkan bahwa jumlah rerata eksresi udang vaname yang dibudidayakan di tambak superintensif sebesar $0,09 \mathrm{mg} / \mathrm{jam} / \mathrm{g}$ udang atau 2,36 $\mathrm{mg} / \mathrm{hari} / \mathrm{g}$ udang. Nilai tersebut merupakan rerata dari hasil pengukuran ekskresi pada bobot udang antara $0,55-10,5$ g. Hasil ini lebih tinggi dengan jumlah ekskresi $\mathrm{N}$ hasil penelitian sebelumnya yaitu sebesar 0,08 $\mathrm{mg} / \mathrm{jam} / \mathrm{g}$. Terjadinya perbedaan nilai ekskresi nitrogen $(\mathrm{N})$ udang erat kaitannya dengan kondisi molting, kondisi pemberian pakan, dan tingkat aktifitas (Comoglio et al., 2004). Berdasarkan hasil tersebut maka dapat diestimasi jumlah nitrogen $(\mathrm{N})$ yang berasal dari ekskresi yang terbuang di perairan Teluk Labuange yaitu sebanyak 0,01 ton atau sekitar $10 \mathrm{~kg}$ nitrogen (N). Selanjutnya, analisis kandungan fosfat $(\mathrm{P})$ pada ekskresi udang menunjukkan bahwa ekskresi udang tidak mengandung fosfat $(\mathrm{P})$. Ponce-Palafox et al. (2017) mengatakan bahwa tingkat ekskresinya lebih rendah pada pemberian pakan yang mengandung protein $20 \%$, tetapi jumlah ekskresinya lebih tinggi pada kadar protein yang tinggi, namun demikian tingkat ekskresi tidak berbeda pada kadar protein pakan $30 \%$ dan $40 \%$.

\subsection{Total Limbah Organik}

Total limbah organik yang masuk dalam perairan Teluk Labuange yang berasal dari kegiatan tambak superintensif dalam bentuk nitrogen $(\mathrm{N})$ sebesar 3,61 ton dan fosfat (P) sebesar 0,28 ton (Table 3). Nitrogen $(\mathrm{N})$ yang berasal dari pakan yang terbuang selama budi daya merupakan penyumbang terbesar dari total nitrogen $(\mathrm{N})$ yang masuk dalam perairan Teluk Labuange yaitu sebesar $67,59 \%$, selanjutnya pakan yang tidak dicerna sebesar $32,13 \%$ dan ekskresi sebesar $0,38 \%$. Penyumbang terbesar limbah organik dalam bentuk fosfat $(\mathrm{P})$ yang berasal dari tambak superintensif yang masuk dalam perairan Teluk Labuange adalah yang bersumber dari pakan yang terbuang yaitu sebesar $99,08 \%$, dari pakan yang tidak tercerna sebesar $0,92 \%$. Tacon et al. (2002), menjelaskan bahwa air kolam dalam budi daya dapat mengakumulasi konsentrasi amonia $(>0,3 \mathrm{mg} / \mathrm{L})$ dan nitrit $(>0,008 \mathrm{mg} / \mathrm{L})$ yang tinggi sebagai hasil ekskresi dan mineralisasi detritus organik, seperti pakan yang tidak dimanfaatkan oleh udang.

Peningkatan nitrogen $(\mathrm{N})$ yang terbuang ke perairan pantai dapat menyebabkan hipoksia. Konsentrasi nitrogen (N) yang tidak terkendali dapat merangsang partumbuhan alga, dan ketika ganggang tenggelam ke bagian bawah perairan dan mati, selanjutnya didekomposisi oleh bakteri yang menggunakan oksigen lebih besar dari produksi oksigen di permukaan yang menyebabkan hipoksia (Rabalais et al., 2002). 
Table 3. Sources of organic waste $(N$ and $P$ ) from the superintensive ponds that enter the Labuange Bay watershed annually.

\begin{tabular}{clcccc}
\hline No. & Source of organic waste & $\begin{array}{c}N \\
\text { (Ton/year) }\end{array}$ & $\begin{array}{c}N \\
(\mathrm{~kg} / \text { day) }\end{array}$ & $\begin{array}{c}P \\
\text { (Ton/year) }\end{array}$ & $\begin{array}{c}P \\
\text { (Tons/ day) }\end{array}$ \\
\hline 1 & Wasted food during cultivation & 2.44 & 6.97 & 0.28 & 0.8 \\
2 & Feed that is not digested & 1.16 & 3.31 & 0.0026 & 0.007 \\
3 & Excretion & 0.014 & 0.04 & 0 & 0 \\
\hline & Total & 3.61 & 10.31 & 0.2826 & 0.81 \\
\hline
\end{tabular}

\section{KESIMPULAN}

Jumlah pakan yang terbuang ke lingkungan dari tambak superintensif sebesar $24,32 \%$ dari total pakan yang digunakan. Beban limbah organik dari tambak udang superintensif yang terbuang ke perairan Teluk Labuange sebesar 3,89 ton terdiri dari limbah organik mengandung $\mathrm{N}$ sebesar 3,61 ton/tahun dengan rerata buangan ke perairan $10,31 \mathrm{~kg} / \mathrm{hari}$, dan limbah organik mengandung $\mathrm{P}$ sebesar 0,28 ton/tahun dengan rerata buangan ke perairan $0,81 \mathrm{~kg} /$ hari.

\section{UCAPAN TERIMAKASIH}

Pelaksanaan penelitian ini melibatkan banyak pihak sehingga itu penulis mengucapkan terima kasih kepada Andi Parendrengi, Rachmansyah, Makmur, Muhammad Chaidir Undu, Hamsah dan semua teknisi di Instalasi Tambak Percobaan Kabupaten Takalar atas segala fasilitas dan bantuan yang diberikan selama penelitian berlangsung.

\section{DAFTAR PUSTAKA}

Association of Official Analytical Chemists (AOAC). 1990. Official Methods of Analysis: Changes in Official Methods of Analysis Made at the Annual Meeting. Supplement (Vol. 15). Association of Official Analytical Chemists. USA. 771 p.

Barg, U.C. 1992. Guidelines of the promotion of environmental management of coastal aquaculture development. FAO Fisheries Technical Paper 328. FAO. Rome. $122 \mathrm{p}$.

Boyd, C. \& J. Clay. 2002. Evaluation of Belize Aquaculture Ltd: A superintensive shrimp aquaculture system. FAO. USA. 25 p.

Boyd, C.E. \& C.S. Tucker. 2012. Pond aquaculture water quality management. Springer Science \& Business Media, LLC. USA. 699 p.

Comoglio, L.I., G. Gaxiola, A. Roque, G. Cuzon, \& O. Amin. 2004. The effect of starvation on refeeding, digestive enzyme activity, oxygen consumption, and ammonia excretion in juvenile white shrimp Litopenaeus vannamei. J. of Shellfish Research, 23(1): 243-249.

https://archimer.ifremer.fr/doc/00000/ 10877/7911.pdf

De Carvalho, C.V., A. Bianchini, M.B. Tesser, \& L.A. Sampaio. 2010. The effect of protein levels on growth, postprandial excretion and tryptic activity of juvenile mullet Mugil platanus (Günther). Aquaculture research, 41(4): 511-518.

https://doi.org/10.1111/j.13652109.2009.02340.x

Furuichi, M. 1988. Dietary requirement. In: Watanabe, T (Ed.), Fish Nutrition and Mariculture. JICA Kanagawa International Fisheries Training Centre. Tokyo. 78 p.

González, F.U.T., J.A. Herrera-Silveira, \& M.L. Aguirre-Macedo. 2008. Water quality variability and eutrophic 
trends in karstic tropical coastal lagoons of the Yucatán Peninsula. Estuarine, Coastal and Shelf Science, 76(2): 418-430.

https://doi.org/10.1016/j.ecss.2007.07 .025

Kawasaki, N., M.R.M. Kushairi, N. Nagao, F. Yusoff, A. Imai, \& A. Kohzu. 2016. Release of Nitrogen and Phosphorus from Aquaculture Farms to Selangor River, Malaysia. International $J$. of Environmental Science and Development, 7(2): 113116.

https://doi.org/10.7763/IJESD.2016.V 7.751

Paerl, H.W. 1997. Coastal eutrophication and harmful algal blooms: Importance of atmospheric deposition and groundwater as "new" nitrogen and other nutrient sources. Limnology and oceanography, 42(5part2): 11541165.

https://doi.org/10.4319/lo.1997.42.5_ part_2.1154

Ponce-Palafox, J.T., H. Esparza-Leal, J.L. Arredondo-Figueroa, C.A. MartinezPalacios, \& L.G. Ross. 2017. The effect of protein and lipid level on the specific dynamic action and postprandial nitrogen excretion in subadult of white shrimp Litopenaeus vannamei. Revista de Biología Marina y Oceanografía, 52(1): 131141.

https://www.redalyc.org/pdf/479/479 50143011.pdf

Rabalais, N.N., R.E. Turner, \& W.J. Wiseman Jr. 2002. Gulf of Mexico hypoxia, aka "The dead zone". Annual Review of ecology and Systematics, 33(1): 235-263.

https://doi.org/10.1146/annurev.ecols ys.33.010802.150513.

Rurangwa, E., U. Baumgartner, H.M. Nguyen, \& J.W.V.D Vis. 2016. Aquaculture Innovation in Vietnam.
Wageningen University and

Research. 28 p.

Schwitzguébel, J.P. \& H. Wang. 2007.

Environmental impact of aquaculture and countermeasures to aquaculture pollution in China. Environmental Science and Pollution Research, 14(7): 452-462.

http://doi.org/10.1065/espr2007.05.42 6

Silva, K.R., W. Wasielesky, \& P.C. Abreu. 2013. Nitrogen and phosphorus dynamics in the biofloc production of the pacific white shrimp, Litopenaeus vannamei. J. of the World Aquaculture Society, 44(1): 30-41. https://doi.org/10.1111/jwas.12009

Suwoyo, H.S., S. Tahe, \& M. Fahrur. 2015. Karakteristik limbah sedimen tambak udang vaname (Litopenaeus vannamei) super intensif dengan kepadatan berbeda. Prosiding Forum Inovasi Teknologi Akuakultur, 901$913 \mathrm{pp}$.

Suwoyo, H.S., M. Fahrur, M. Makmur, \& R. Syah. 2017. Pemanfaatan limbah tambak udang super intensif sebagai pupuk organik untuk pertumbuhan biomassa kelekap dan nener bandeng. Media Akuakultur, 11(2): 97-110. http://doi.org/10.15578/ma.11.2.2016. 97-110

Tacon, A.G.J., J.J. Cody, L.D. Conquest, S. Divakaran, I.P. Forster, \& O.E. Decamp. 2002. Effect of culture system on the nutrition and growth performance of Pacific white shrimp Litopenaeus vannamei (Boone) fed different diets. Aquaculture nutrition, 8(2): 121-137. https://doi.org/10.1046/j.13652095.2002.00199.x

Thakur, D.P. \& C.K. Lin. 2003. Water quality and nutrient budget in closed shrimp (Penaeus monodon) culture systems. Aquacultural Engineering, 27: 159-176. 
https://doi.org/10.1016/S01448609(02)00055-9

Teichert-Coddington, D.R., D. Martinez, \& E. Ramirez. 2000. Partial nutrient budgets for semi-intensive shrimp farms in Honduras. Aquaculture, 190(1): 139-154. https://doi.org/10.1016/S00448486(00)00389-6

Tirkaso, W. \& I.M. Gren. 2016. Habitat quality and fish population: impacts of nutrient enrichment on populations of European perch off the east coast of Sweden, 3:1-21 pp.

Wasielesky, W., H. Atwood, A. Stokes, \& C.L. Browdy. 2006. Effect of natural production in a zero exchange suspended microbial floc based super-intensive culture system for white shrimp Litopenaeus vannamei. Aquaculture, 258(1): 396-403. https://doi.org/10.1016/j.aquaculture. 2006.04.030

Watanabe, T. 1988. Fish Nutrition and Mariculture. JICA Textbook the General Aquaculture Courese. Departement of Aquatic Biosciences, Tokyo University of Fisheries. Japan. $233 \mathrm{p}$.

Williamson, S.C., J.E. Rheuban, J.E. Costa, D.M. Glover, \& S.C. Doney. 2017. Assessing the impact of local and regional influences on nitrogen loads to Buzzards Bay, MA. Front. Mar. Sci., 3: 1-17.

https://doi.org/10.3389/fmars.2016.00 279

Received : 13 December 2019

Reviewed : 24 May 2020

Accepted : 19 August 2020 